\title{
Viability of simultaneous genotypic screening and germination of individual seeds in rice, beans and maize
}

\author{
R.R. de Brito ${ }^{1}$, E.F. Leão-Araújo ${ }^{2}$, L.B. da S. Ferreira ${ }^{2}$, L. de M.O. \\ Mendes ${ }^{1}$, C.C. de O. Pereira ${ }^{1}$, J.O. da Silva ${ }^{1}$, E. Bógea ${ }^{1}$, L.V. Hoffmann ${ }^{3}$ \\ and I.P.P. de Menezes ${ }^{1}$ \\ ${ }^{1}$ Laboratório de Genética Molecular, Instituto Federal Goiano, Urutaí, GO, \\ Brasil \\ ${ }^{2}$ Laboratório de Sementes, Instituto Federal Goiano - Campus Urutaí, GO, \\ Brasil \\ ${ }^{3}$ Laboratório de Biotecnologia Vegetal, Embrapa Arroz e Feijão, Santo \\ Antônio de Goiás, GO, Brasil \\ Corresponding author: I.P.P de Menezes \\ E-mail: ivan.menezes@ifgoiano.edu.br
}

Genet. Mol. Res. 18 (1): gmr18130

Received August 28, 2018

Accepted January 31, 2019

Published February 25, 2019

DOI http://dx.doi.org/10.4238/gmr18130

\begin{abstract}
DNA-assisted selection can be applied to vegetal species in the seed stage; however, little is known about the effect of seed fractionation on the physiological quality and viability of the seedlings or the effectiveness of DNA extraction from seed pieces. We evaluated the efficiency of pre-germinative genotypic screening by DNA markers from manually cut partial seeds of rice, beans and maize. Tests to evaluate PCR amplification and physiological quality were performed. We observed that the Sarkosyl method was efficient to extract DNA from a $1 / 2$ fraction of the rice seeds and $1 / 4$ of the bean and maize seeds, generating good quality SSRPCR products. The physiological quality of the rice seeds cut in half and the bean and maize seeds remaining fraction of $3 / 4$ of the original seed provided a high germination percentage. The method is effective for simultaneously genotyping and germinating plants from a single seed, since DNA extracted from these fractions of seeds can be used for studies with DNA markers, while the remaining portions can be used for seedling production.
\end{abstract}

Key words: Assisted selection; DNA extraction; DNA marker; Viability; Vigor 


\section{INTRODUCTION}

The development and use of DNA markers for breeding programs and studies of prospecting genetic resources have brought advances in the process of identifying relevant genetic variation and selection in several agricultural crops (Nascimento, 2015; Carvalho, 2016; Barreto et al., 2017). Marker-assisted selection (MAS) has an important role on phenotyping and increased efficiency in selective processes in modern plant and animal breeding (Toppa and Jadoski, 2013).

MAS is used in several commercial crops; for example, the common bean (Faleiro et al., 2004), maize (Prasanna et al., 2010), rice (Tabien et al., 2000; Gouda et al., 2013), cotton (Fang et al., 2010; Xiao et al., 2010), and soybean (Santana et al., 2014). Although MAS is a selection strategy that is being increasingly used in public and private research institutions worldwide, it tends to be predominantly based on DNA genotyping systems obtained from young leaves (Yap et al., 2016; Alkimim et al., 2017; Qi et al., 2017).

Pre-germination Genotyping Systems is the process of selecting genotypes from seed DNA. This process significantly decreases the costs and time of selection when compared to DNA extraction from leaves, since it is not necessary to sow and wait for plant emergence, especially useful for molecular breeding programs that select from thousands of candidates (Duan et al., 2015; Yap et al., 2016). Automated equipment has been built and marketed for this purpose, in which fractions of the seeds are laser cut on a large scale, increasing accuracy and reducing the risks of damage or loss of seed material. However, such equipment is not accessible to smaller breeding programs and the majority of public education and research institutions due to their high cost.

Studies have emphasized the efficiency of DNA microextraction from manually-cut seed fractions, as opposed to the automated seed fractionation for DNA extraction (Gao et al., 2008; Duan et al., 2015). However, there is a lack of studies on the physiological quality of the plant obtained from seed fractions consequently, complementary studies are necessary to determine the efficiency of pre-germination systems in non-automated genotyping.

To develop a cost-effective method for simultaneously genotyping and germinating plants from a single seed, we evaluated the quality and quantity of DNA, as well as the physiological quality of the plant regenerated from fractions of seeds of rice, common beans and maize that are manually cut for marker-assisted selection studies. We consider the hypothesis that the system of pre-germination genotyping from seeds with $1 / 2$ and $3 / 4$ of the seed, cut manually, does not affect the physiological quality of the seedlings and that the quality and quantity of DNA from $1 / 2$ or $1 / 4$ of the seeds are suitable for marker-assisted selection studies in rice, common bean and corn.

\section{MATERIAL AND METHODS}

\section{Plant Material}

For species selection we considered the economic value of the crops, and the existence of DNA markers linked to genes of interest in breeding programs. The selected species were rice, beans and maize: Oryza sativa, Phaseolus vulgaris and Zea mays, 
respectively. Selected seeds from a single adapted genotype (commercial variety or breeding lineage) of each species were used.

The morphological characteristics of the seeds, which can correlate with physiological quality, were also observed. Common bean seeds are exalbuminous, with a cotyledonary reserve, mainly composed of proteins; and the embryonic axis structure is located in the upper portion of the embryo. On the other hand, maize and rice have albuminous seeds, with an endospermic reserve rich in starch. In the case of maize, the embryo is in the central portion of the seed and protected by a scutellum, and in the case of rice the embryo is located in the upper portion of the seed (Fujisawa et al., 1999; Ista 2008; Rana et al., 2010).

\section{DNA Extraction and PCR}

Seeds were measured using a digital caliper. An approximate fraction of $1 / 4$ of bean seeds and $1 / 2$ of maize or rice seeds was cut with the aid of a number 24 scalpel.

Prior maceration tests, with different sizes of stainless steel spheres $(4,6$ and 8 $\mathrm{mm})$, were performed with three replicates. Fractions (1/4 or 1/2) of the seeds of each species were placed in $2-\mathrm{mL}$ tubes with $300 \mu \mathrm{L}$ of one of the extraction buffers and a stainless steel sphere and kept overnight. After that, the tubes were put in an appropriate rack and strong movements (up and down) were applied during $30 \mathrm{~s}$ for maceration.

The extraction buffers were prepared accordingly to three previously described extraction methods to be tested for each species, CTAB 2\% (Doyle and Doyle, 1987), SDS (Mc Donald et al., 1994), and Sarkosyl (Souza et al., 2012). The methods were previously tested with five replicates, separately, for each species. Aliquots of the total volume of extracted DNA were quantified by visual comparison with the generated bands of a series of known concentrations of $\lambda$ phage DNA $(50,100$ and $200 \mathrm{ng}$ ) on agarose gels $(0.8 \%)$, stained with ethidium bromide. The DNA was diluted in water at a concentration of 10 ng. $\mu \mathrm{L}^{-1}$.

The extracted DNA samples were tested in PCRs, using a single primer of chloroplast microsatellite (universal cpSSR), the primer Ccmp02, developed by Weising and Gardner (1999). PCR and amplification conditions performed in thermal cycler were conducted as described by Weising and Gardner (1999). The PCR product was applied on $3 \%$ agarose gels and stained with ethidium bromide.

\section{Analysis of physiological quality}

For the bioassays of the physiological quality analysis (PQ), $3 / 4$ and $1 / 2$ fractions of beans and maize seeds, and $1 / 2$ fraction of rice seeds, were compared to whole seeds of the same species. The cuts were performed separately for each seed, so that it did not reach the embryo/embryonic axis region, with a number 24 scalpel. The experiments were conducted individually for each species, in a completely randomized design with four replications. The treatments, for all species (rice $-\mathrm{R}$, beans $-\mathrm{B}$, and maize - M), consisted of whole seeds (RW, BW and MW), a fraction of $3 / 4$ of the seed $\left(B^{3} / 4\right.$ and $\left.M^{3} / 4\right)$ and a fraction of $1 / 2\left(R^{1 / 2}, B^{1 / 2}\right.$ and $\mathrm{M} 1 \frac{1}{2}$ ).

The germination test (GT) was conducted following the procedures described in the Rules for Seed Analysis (Brazil, 2009) for each species, with replicates composed of 50 
seeds, on germination paper, which was moistened with deionized water equivalent to 2.5 times the dry mass of the substrate. The rolls of paper were kept in a germinator chamber at $25^{\circ} \mathrm{C}$, packed in plastic bags. The germination was observed at 14, 9, 7 days after the seeds had been put in paper, for rice, beans and maize respectively. The results were expressed as a percentage.

The germination first count (GFC), which is indicative of the seeds vigor, consisted of the determination, in percentage, of normal seedlings. It was carried out along with the GT, but the evaluations were earlier, at the first count, five days after sowing for rice and beans and four days for maize, established in the RAS (Brazil, 2009). For the GSI (Germination speed index) test, which is also a vigor test, daily counts of normal seedlings were performed and the results were used to determine the index.

On the last day of the germination test $(14,9$ and 7 for rice, beans and maize, respectively), the total fresh mass (TFM) and total dry mass (TDM) tests were measured for beans and maize, and for rice the TFM, fresh root mass (FRM) and fresh shoot mass (FSM) tests, which consisted of the removal and counting of the normal and abnormal seedlings of each replicate. Only the normal seedlings were used for these measures; for rice the normal seedlings were cut with a scalpel, removing the residues from the reserve tissue, detaching the root system from the aerial part. Then, they were placed in paper envelopes and weighed. The seedlings were subsequently dried in an oven set at $60^{\circ} \mathrm{C}$ for $48 \mathrm{~h}$. Then the samples were cooled to room temperature and weighed. The results were expressed in $\mathrm{mg}$ seedling ${ }^{-1}$. Variances were compared by the $F$ test, and means by the $T$ test, two by two. To illustrate the comparisons, graphs with $95 \%$ confidence intervals were generated. This analysis was performed using the $\mathrm{R}$ package.

\section{RESULTS AND DISCUSSION}

\section{DNA Extraction and PCR}

Total crushing of the rice, bean and maize endosperm was only accomplished with 8-mm spheres (large size) after $30 \mathrm{~s}$ of maceration. Seed crushing with 4- and 6-mm spheres was not efficient. Thus, we suggest that the $8-\mathrm{mm}$ spheres are best for crushing these seeds.

DNA extraction was best achieved using the Sarkosyl method, based on DNA quantification (Figure 1). Maize and beans DNA presented larger pellets with a white color, when compared to DNA extracted by the SDS or CTAB methods, which led to smaller and darker pellets (precipitated DNA). The dark color indicates oxidation of the plant material and, consequently, DNA degradation and loss in quality (Costa and Moura, 2001). For rice, it was only possible to extract DNA using the Sarkosyl method and only after increasing the fraction from $1 / 4$ to $1 / 2$ of the seed. The amount of DNA obtained from the seed portion was similar for the three species, around $100 \mathrm{ng} / \mu \mathrm{L}$, which is enough to carry out PCR reactions, and the double the $50 \mathrm{ng}$ of DNA which that is considered a minimum quantity (Buso et al., 2003).

The amount of DNA obtained from the endosperm varies not only as a function of the abundance of plant material (Duan et al., 2015), but also according to the method used, and the type of sample (Chunwongse et al., 1993; Souza et al., 2012). The Sarkosyl method was efficient to obtain good amounts of DNA from small and dense seeds, such as rice, beans and maize. This result indicates a satisfactory alternative for obtaining DNA from 
seeds with large amounts of starch, such as bean and maize seeds, since the high amount of polysaccharides reduces efficiency in obtaining DNA (Chunwongse et al., 1993).
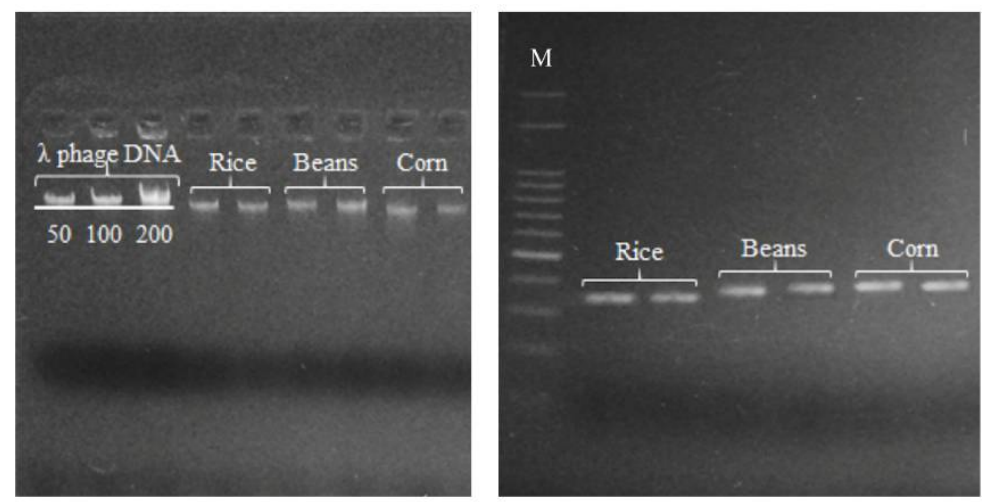

Figure 1. Gel electrophoresis ( $0.8 \%$ agarose) of extracted DNA (a) and gel electrophoresis (3\% agarose) of PCR amplification from primers Ccmp02 (b). Lanes $\lambda$ phage DNA is a lambda DNA size marker and lane M is a $50 \mathrm{bp}$ DNA ladder (Ludwing).

Figure 1 show that the quality of DNA obtained from the seed fractions was satisfactory, with no indication of degraded DNA (no trace of DNA above the band in the gel) and polysaccharides (DNA trapped in gel wells). The absence of these characteristics increases the chance of success of the amplification of DNA markers, since contamination with polysaccharides, degrades DNA, and results in production of secondary metabolites, for example, causing PCR amplification failures (Souza et al., 2012) or at any subsequent stage of DNA use (Costa and Moura, 2001). Thus, as an additional indication of the quality of the DNA that we extracted, we used a PCR amplification test.

PCR performed using cpSSR (Ccmp02) produced clear amplification fragments with base pair size in the range of 150-200 bp (Figure 1). This variation comprises the expected size range for the respective amplified loci, as described by Weising and Gardner (1999), confirming the amplified PCR product. The quality and quantity of the extracted DNA can be evaluated in different ways, and this is a step of extreme importance to obtain good efficiency in PCR reactions.

\section{Analysis of physiological quality}

The $50 \%$ cut of rice seeds ( $\mathrm{R} 1 / 2)$ significantly decreased in germination when compared to whole seeds (P-value $<0.05$ ), with means of $67.5 \%$ and $80.5 \%$, respectively (Figure 2A). The same behavior was observed when we evaluated the vigor with the GFC (Figure $2 \mathrm{~B}$ ). The vigor of rice seedlings for $\mathrm{R} 1 / 2$ seeds was also significantly affected, as indicated by a comparison of initial development of the seedling through GSI, FRM, FSM, and TFM (Figure 2C, D, E and F).

According to Brazil (2009), GT aims to determine the maximum germination potential of a seed lot, which can be used to compare the quality of different lots. Based on this principle, $\mathrm{R} 1 / 2$ replicates are affected when compared to RW replicates. This result is related to the cutting procedure, which removed half of the energy reserves of the seed, causing alterations in the formation of the seedlings. 

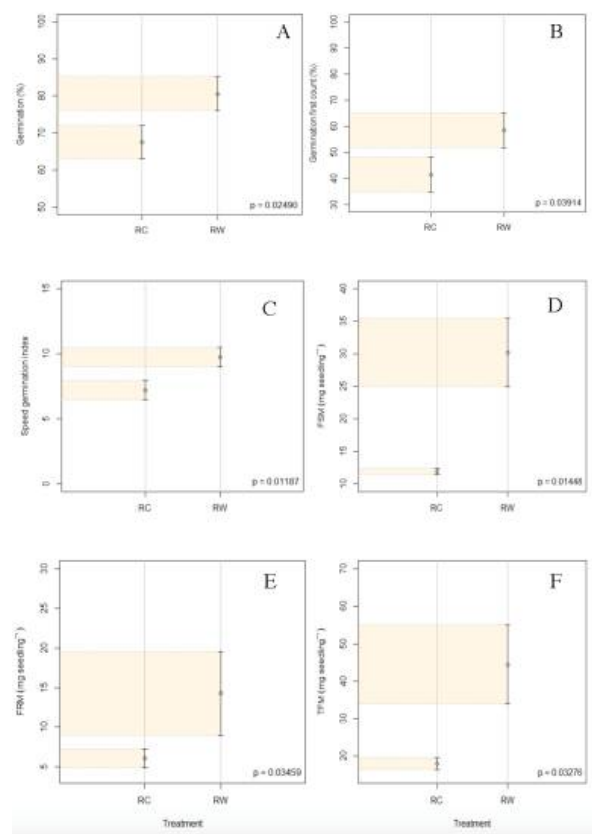

Figure 2. Physiological quality of whole (RW) and cut rice seeds ( $\mathrm{RC}$ or $\mathrm{R} 1 / 2$ - which refers to $50 \%$ of the seed). (a) Germination; (b) Germination first count; (c) Germination speed index; (d) Fresh shoot mass; (e) Fresh root mass; (f) Total fresh mass.

It is known that the nutritive reserve in seeds is essential for their vital functions and that drastic reductions affect the normal development of the seedlings (Marcos-Filho, 2015), as well as physiological changes that are characterized by the low percentage of germination of the seeds, slow growth of seedlings and production of abnormal seedlings (Krzyzanowski and França-Neto, 2001). Although the cut impaired the vigor and viability of the seeds, we observed that the seeds $\mathrm{R}$ still had germination values above $60 \%$, which allows the use of these cuts for DNA extraction and then the use of the remnant to form the seedling.

Cuts of $75 \%$ of rice seeds (A 3/4) were also performed and significant losses in GT, SGI, FRM, FSM and TMF were not observed when compared to whole seedlings. However, we could not obtain genomic DNA from the 25\% portion of the rice seed (A $1 / 4)$. Unlike rice, we could extract DNA from the portion (A $1 / 4)$ of both bean and corn seeds, thus we present the results of the analysis of the physiological quality for the portions of $1 / 2,3 / 4$ and whole seeds.

For beans, we found that there was no significant difference ( $p$-value> 0.5$)$ between the germination percentage for whole seeds (BW) and B 3/4, with mean values of 83 and $84.5 \%$, respectively (Figure 3A, Table 1). This test, GT, indicates that even after reducing the energy reserves by $25 \%$, the seeds presented germination capacity with equal percentages compared to whole seeds. Complementary to GT, we found that seeds with $75 \%$ of their total portion presented the same vigor of the seeds without cuts, as demonstrated by the GFC, GSI, TFM and TDM tests (Figure 3B, C, D and E). 

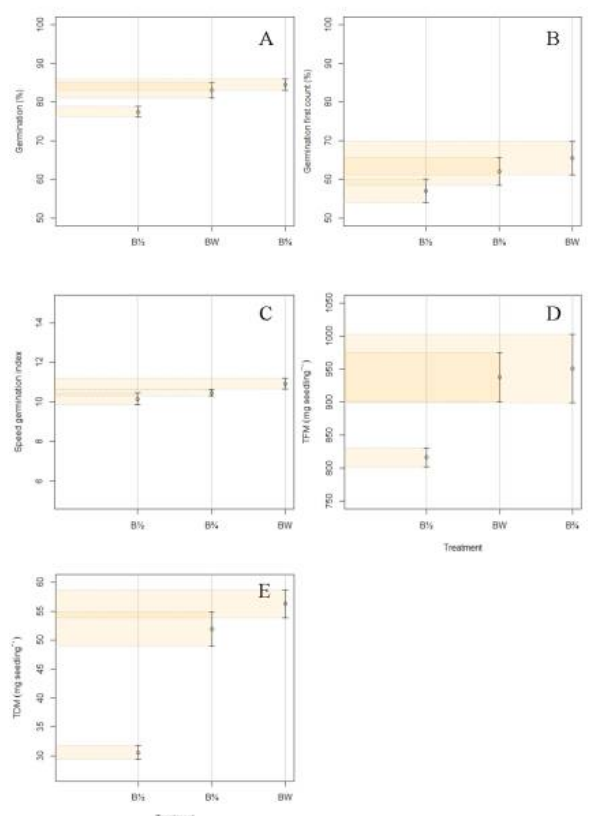

Figure 3. Physiological quality of whole (BW) and cut bean seeds (B $3 / 4$ - which refers to $25 \%$ of the seed removed and B $1 / 2$ - which refers to $50 \%$ of the seed removed). (a) Germination; (b) Germination first count; (c) Germination speed index; (d) Total fresh mass; (e) Total dry mass.

Table 1. P-value obtained for the comparisons of test means and physiological quality for beans (B) and maize (M) seeds.

\begin{tabular}{|c|c|c|c|c|c|c|}
\hline $\begin{array}{l}\text { Physiological } \\
\text { quality tests }\end{array}$ & BW x B $3 / 4$ & BW $\times \mathbf{B}^{1} \frac{1}{2}$ & $\mathbf{B}^{3} / 4 \times \mathbf{B}^{1} 1 / 2$ & $\begin{array}{l}\text { value } \\
\text { MW } \times M^{3} / 4\end{array}$ & MW $\mathbf{x} \mathbf{M}^{1} 1 / 2$ & $\mathbf{M}^{3} / 4 \times \mathbf{M}^{1} 1 / 2$ \\
\hline GT & $0.51^{\text {ns }}$ & $0.04 *$ & $0.01^{*}$ & $0.26^{\mathrm{ns}}$ & $0.62^{\mathrm{ns}}$ & $0.19^{\mathrm{ns}}$ \\
\hline GFC & $0.50^{\mathrm{ns}}$ & $0.12^{\mathrm{ns}}$ & $0.27^{\mathrm{ns}}$ & $0.17^{\mathrm{ns}}$ & $0.04 *$ & $0.01 *$ \\
\hline GSI & $0.16^{\text {ns }}$ & $0.07^{\text {ns }}$ & $0.35^{\text {ns }}$ & $0.07^{\mathrm{ns}}$ & $0.87^{\text {ns }}$ & $0.13^{\text {ns }}$ \\
\hline TFM & $0.82^{\mathrm{ns}}$ & $0.03^{*}$ & $0.04 *$ & $0.01 *$ & $0.00002^{*}$ & $0.003 *$ \\
\hline TDM & $0.24^{\mathrm{ns}}$ & $0.0003 *$ & $0.002 *$ & $0.0004^{*}$ & $8.995 \mathrm{e}-07 *$ & $0.0002^{*}$ \\
\hline
\end{tabular}

* P-value < 0.05; ${ }^{\text {ns }}$ not significant. GT - Germination Test, GFC - First Germination Count, GSI Germination Speed Index, TFM - Total Fresh Mass, TDM - Total Dry Mass.

There was no difference in the normal seedling percentage of bean seeds with $25 \%$ of the reserve cut off. These results are related to the volume cut off from the reserve, which may not have significantly affected the main sources of reserves for developing-seedling nutrition. For many seeds, as well as for beans, this reserve is in the cotyledons, which is part of the embryo and have a large volume of reserves. These structures (cotyledons) are responsible for nourishing the embryo during its development and they contain all the nutrients essential for the formation of the seedling (Marcos-Filho, 2015).

In contrast, the B $1 / 2$ seeds were affected by the $50 \%$ cuts, with significantly lower GT $(77.5 \%, \mathrm{P}<0.05)$. This result, as well as for rice, is related to the loss of a large portion of the essential nutrients for the formation of normal seedlings, resulting in a low percentage of germination. Although this cut fraction did not cause significant losses in germination speed (GFC and GSI), it significantly reduced the initial development of the seedlings (TFM and TDM). The different vigor tests have distinct capacities to detect subtle 
properties of physiological quality (Rocha et al., 2017) that are not revealed in a germination test.

For B $1 / 2$ seeds, seed vigor evaluated by the germination speed was equal to those obtained for whole seeds only in the GFC and GSI tests (Figures 3B and C). Thus, B $1 / 2$ seeds may have germination rates equal to the seeds BW and B $3 / 4$ because the mobilization of the reserves occurs faster, since less water is required to hydrate smaller seeds and for biochemical reactions in the reserve tissues.

For maize, the result for GT obtained from seed portions M 1/2, M 3/4 and MW was greater than $85 \%$ and statistically similar $(\mathrm{P}>0.5)$ (Figure 4A, Table 1). Similarly, an absence of difference in germination velocity evaluated by the GFC was observed comparing MW and $\mathrm{M} 3 / 4$, although the percentage of normal seedlings in GFC test was significantly different from that of $\mathrm{M}^{1} \frac{1}{2}$ (Figure 4B). However, a significant reduction in initial vegetative growth was observed when removing part of the energy reserve with the cuts $\mathrm{M} 1 / 2, \mathrm{M} 3 / 4$, as indicated for TFM and TDM $(\mathrm{P}<0.05)$ (Figure 4D and E).
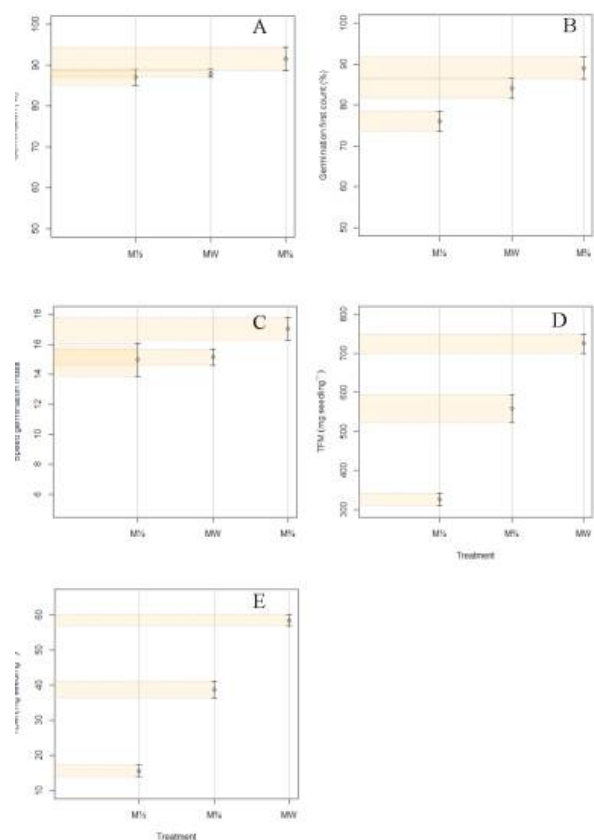

Figure 4. Physiological quality of whole (MW) and cut maize seeds ( $\mathrm{M} 3 / 4$ - which refers to $25 \%$ of the seed removed and $\mathrm{M} 1 / 2$ - which refers to $50 \%$ of the seed removed). (a) Germination; (b) Germination first count; (c) Germination speed index; (d) Total fresh mass; (e) Total dry mass.

The GSI was higher in $\mathrm{M} 3 / 4$ compared to the whole seed; this increase is related to the rupture of the external barrier (seed coat) through cutting, which allowed the rapid absorption of water and activation of metabolism for germination. The higher the GSI, the greater the germination speed, since the calculated index estimates the average number of normal seedlings per day (Maguire, 1962). According to Marcos-Filho (2015), seeds that have damage to the tegument generally have a lower physiological potential (vigor), but greater permeability to water, and a greater initial availability of water can accelerate 
imbibition of the seeds, contributing to the processes of mobilization of the reserves (Carvalho and Nakagawa, 2000).

Loss of part of the seeds can lead to different effects in deterioration or vigor in different types of seeds and species, caused by the different biochemical and physiological changes that occur in the seeds (Krzyzanowski and França-Neto, 2001). In addition, it may make the seeds more susceptible to pathogen infection (Chunwongse et al., 1993).

As a criterion to minimize losses due to the viability of the cut seeds, we can consider the MAPA (2013) orientation regarding the standard for seed production and commercialization, which establishes a minimum germination value of $80 \%$ for both rice and beans; and $85 \%$ for maize. Therefore, this expected value corresponds to that obtained for $3 / 4$ of the bean seed, $3 / 4$ and $1 / 2$ of the maize seed, with extraction of DNA in adequate quantities from the complementary fraction of $1 / 4$ or $1 / 2$.

The cuts $3 / 4$ of the bean and $3 / 4$ and $1 / 2$ maize seeds for seedling formation are appropriate for the use of these species in a program of pre-germinative genotyping by DNA markers, using the remnant for DNA extraction. However, these limits could not be defined for rice, due to the $\mathrm{R} 1 / 2$ low seed viability and the failure to obtain DNA from the $\mathrm{R}^{1 / 4}$ fraction. Finally, we can conclude that fractionation of seeds for DNA extraction and planting in marker-assisted selection program cannot be the same or standardized in the different species or types of seeds. DNA extraction strategies from portions of manually-cut seeds can be used in pre-germinative genotyping of maize, beans and rice.

\section{ACKNOWLEDGMENTS}

We thank CNPq for providing a scholarship to the first author and to the Instituto Federal Goiano (Brazil) for financial research support.

\section{Conflicts of interest}

The authors declare no conflict of interest.

\section{REFERENCES}

Alkimim ER, Caixeta ET, Sousa TV, Pereira AA, et al. (2017). Marker-assisted selection provides arabica coffee with genes from other Coffea species targeting on multiple resistance to rust and coffee berry disease. Mol. Breeding. 37: 1-10.

Barreto FZ, Balsalobre TWA, Chapola RG, Hoffmann HP, et al. (2017). Validação de marcadores moleculares associados à resistência à ferrugem marrom em cana-de-açúcar. Summa Phytopathol. 1: 36-40.

Boesewinkel FD and Bouman F (1995). The seed: structure and function. In: Seed development and germination (Kigel J and Galili G, eds). Marcel Dekker, New York, p. 1-24.

Brasil (2009). Regras para análises de sementes. Brasília: Mapa/ ACS. Available at [www.agricultura.gov.br]. Accessed 26 June 2018.

Carvalho N (2016). Variabilidade genética de linhagens e cultivares de melão utilizando marcadores moleculares. Ph.D. thesis, Universidade de Brasília.

Carvalho NM and Nakagawa J (2000). Sementes: ciência, tecnologia e produção. 4 ed. FUNEP, Jaboticabal.

Chunwongse J, Martin GB and Tanksley SD (1993). Pre-germination genotypic screening using PCR amplification of half-seeds. Theor. Appl. Genet. 86: 694-698.

Costa MR and Moura EF (2001). Manual de extração de DNA. Embrapa Amazônia Oriental.

Duan YB, Zhao FL, Chen HD, Li H, et al. (2015). A simplified genomic DNA extraction protocol for pre-germination genotyping in rice. Genet. Mol. Res. 14: 6369-6375.

Faleiro FG, Ragagnin VA, Moreira MA and Barros EG (2004). Use of molecular markers to accelerate the breeding of common bean lines resistant to rust and anthracnose. Euphytica. 138: 213-218. 
Fang DD, Xiao J, Canci PC and Cantrell RG (2010). A new SNP haplotype associated with blue disease resistance gene in cotton (Gossypium hirsutum L.). Theo. Appl. Genet. 120: 943-953.

Fujisawa Y, Kato T, Ohki S, Ishikawa A, et al. (1999). Suppression of the heterotrimeric G protein causes abnormal morphology, including dwarfism, in rice. Proc. Natl. Acad. Sci USA. 96: 7575-80.

Gao S, Martinez C, Skinner DJ, Krivanek AF, et al. (2013). Development of a seed DNA-based genotyping system for marker-assisted selection in maize. Mol. Breeding. 22: 477-494.

Gouda PK, Saikumar S, Varma CM, Nagesh K, et al. (2013). Marker-assisted breeding of Pi-1 and Piz-5 genes imparting resistance to rice blast in PRR78, restorer line of Pusa RH-10 Basmati rice hybrid. Plant Breeding. 132: 61-69.

ISTA, International Seed Testing Association (2008). The germination test. In: ISTA. International rules for seed testing. Bassersdorf.

Krzyzanowski FC, Vieira RB and França-Neto JB (1999). Vigor de sementes: conceitos e testes. Abrates, Londrina, Paraná.

Krzyzanowski FC and França-Neto JB (2001). Vigor de sementes. Informativo Abrates, Londrina, Paraná.

Maguire JD (1962). Speed of germination- aid in selection and evaluation for seedling emergence and vigor. Crop. Sci. 2: $176-177$

MAPA, Instrução Normativa N 45 de 17 de Setembro de 2013. Available at [http://www.lex.com.br/legis_24861657_I.aspx].

Marcos-Filho J (2015). Fisiologia de sementes de plantas cultivada. Abrates, Londrina, Paraná.

Mc Donald MD, Elliot LJ and Sweeney PM (1994). DNA extraction from dry seeds for RAPD analyses in varietal identification studies. Seed Sci. Technol. 22: 171-176.

Nascimento JB (2015). Diversidade genética e estrutura populacional de Diatraea saccharalis (Fabricius) (Lepidoptera: Crambidae) nas culturas do arroz (Oryza sativa L.) e cana-de-açúcar (Saccharum officinarum L.). Tese, Universidade Federal de Goiás.

Prasanna BM, Pixley K, Warburton ML and Xie CX (2010). Molecular marker-assisted breeding options for maize improvement in Asia. Mol. Breed. 26: 339-356.

Qi LL, Talukder ZI, Hulke BS and Foley ME (2017). Development and dissection of diagnostic SNP markers for the downy mildew resistance genes PlArg and P18 and makerassisted gene pyramiding in sunflower (Helianthus annuus L.). Mol. Genet. Genomics. 292: 551-563.

Rania MA, Nassar Y, Ahmed M and Boghdady MS (2010). Botanical studies on Phaseolus vulgaris L. I-morphology of vegetative and reproductive growth. Int. J. Bot. 6: 323-333.

Rocha GC, Neto AR, Cruz SJS, Campos GWB, et al. (2017). Qualidade fisiológica de sementes de soja tratadas e armazenadas.Científic@-Multidisciplinary J. 1: 50-65.

Santana FA, Silva MFD, Guimarães JKF, Ferreira MFDS, et al. (2014). Marker-assisted selection strategies for developing resistant soybean plants to cyst nematode. Crop Breed Appl Biotechnol. 14: 252-257.

Salles G, Buso C, Ciampi AY, Moretzsohn MC, et al. (2003). Protocolo para desenvolvimento de marcadores microssatélites. Embrapa Hortaliças, Brasília.

Sasaki M (2008). Lipídios, carboidratos e proteínas de sementes de leguminosas do cerrado. Dissertação, Universidade de São Paulo

Souza HAV, Muller LAC, Brandão RL and Lovato MB (2012) Isolation of high quality and polysaccharide-free DNA from leaves of Dimorphandra mollis (Leguminosae), a tree from the Brazilian Cerrado. Genet. Mol. Res. 1: 756764.

Tabien RE, Li Z, Paterson AH, Marchetti MA, et al. (2000). Mapping of four major rice blast resistance genes from 'Lemont' and 'Teqing' and evaluation of their combinatorial effect for field resistance. Theo. Appl. Genet. 10: 11215-1225.

Toppa EVB and Jadoski CJ (2013). O uso dos marcadores moleculares no melhoramento genético de plantas. Rev. Sci. Agrar. Parana. 12: 1-5.

Xiao J, Fang DD, Bhatti M, Hendrix B, et al. (2010). A SNP haplotype associated with a gene resistant to Xanthomonas axonopodis pv. alvacearum in upland cotton (Gossypium hirsutum L.). Mol. Breed. 25: 593-602.

Weising K and Gardner RC (1999) A set of conserved PCR primers for the analysis of simple sequence repeat polymorphisms in chloroplast genomes of dicotyledonous angiosperms. Genome. 49:9-19.

Yap R, Hsu YC, Wu YP, Lin YR, et al. (2016). Multiplex PCR genotyping for five bacterial blight resistance genes applied to marker-assisted selection in rice (Oryza sativa). Plant Breed. 135: 309-317. 